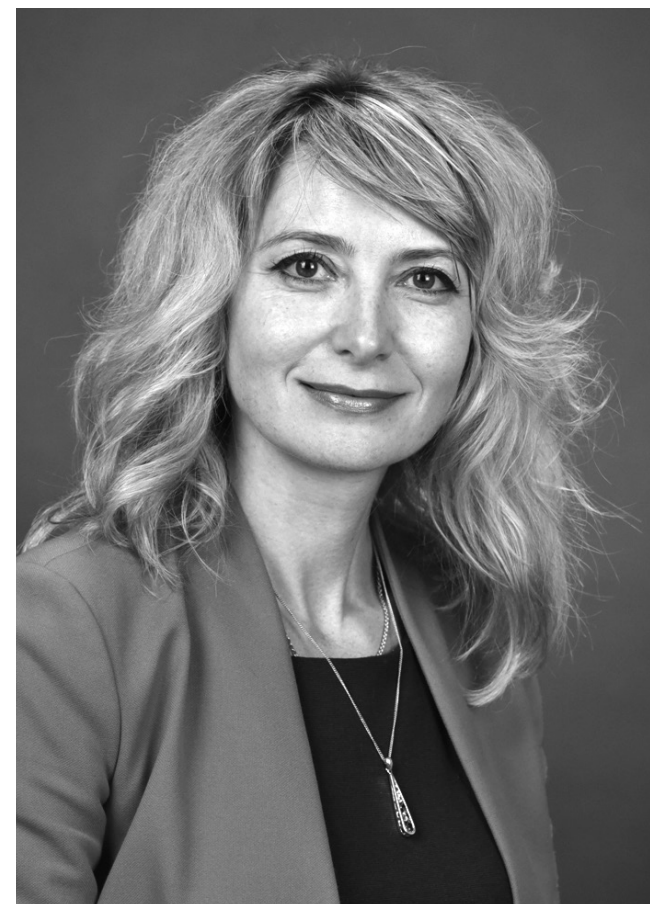

UDC 316.27:159.9

DOI: https://doi.org/10.32689/2617-

2224-2020-1(21)-122-132

Кожем'якіна Оксана Миколаївна, кандидат філософських наук, дочент, дочент кафедри філософських і політичних наук Черкаського державного технологічного університету; 18006, Черкаси, б-р Шевченка, 460; тел.: +38 (097) 53037 24;e-mail: oksniko@ukr.net

ORCID: 0000-0002-7196-4857

Кожемякина Оксана Николаевна, кандидат философских наук, доцент, доцент кафедры философских и политических наук Черкасского государственного технологического университета; 18006, Черкассы, б-р Шевченко, 460; тел.: +38 (097) 53037 24; e-mail: oksniko@ukr.net

ORCID: 0000-0002-7196-4857

Kozhemiakina Oksana Mikolaivna, Ph.D., candidate of philosophical sciences, Associate Professor of Department of Philosophy and Political Science Cherkassy State Technological University; 18006, Cherkasy, Bulvar Shevchenka, 460; тел.: +38 (097) 530 37 24; e-mail: oksniko@ukr.net

ORCID: 0000-0002-7196-4857

\title{
ТРАДИЦІЯ ТА АРХЕТИП: ТВОРЧІ ОСНОВИ ПОСТМОДЕРНОЇ ІНТЕРПРЕТАЦІЇ
}

Анотація. Проаналізовано концептуальне поле постмодерної інтерпретації співвідношення традиційного та інноваційного в аналізі соціальних взаємодій з позицій архетипового підходу. Наголошуючи на єдності теоретичних основ постмодернізму, постструктуралізму та деконструктивізму, розглядаються постмодерні практики демонстрації спроможності людини та спільнот жити в умовах нестабільності, хаотичності та плюральності, за рахунок, зокрема, взаємопроникнення нових та архаїчних форм соціальності. Архетипна природа традицій в наративній постмодерній практиці яскраво виявляється в інтерпретативних сюжетах-іграх та численних перспективах “прочитань” архетипних образів, деконструкціях традиційних способів представлення архетипів в іронічному діалозі з близьким та далеким минулим.

У межах теоретико-методологічних основ постмодернізму досліджуються теорії альтернативних форм самоорганізації, які приходять на зміну модер- 
ним формам соціалізації та базуються на розрізненні соціальної і культурної реальності. Звертаючи увагу на посилення глокальних контекстів глобалізації, розкрито, запропонований М. Маффесолі феномен неотрайбалізму, що базується на таких виразних постмодерних цінностях, як контекстуальна симпатія, общинна емпатія, інклюзивне розмаїття, плюральна толерантність, еклектичність та традиційність. Стверджується, що неотрайбалізм є відображенням справжньої духовної революції сучасного інформаційного суспільства в аспекті формування нової мережевої соціальності на основі вільного вибору культурних цінностей та пропаганди культурно “близького” способу життя. Відтак постмодернізм в аспекті його неоконсервативної суті розуміється як повернення архаїзму, що є джерелом життєвої сили та органічної мобілізації колективної енергії. Неотрайби як екзистенційні мережі “живої соціальності” ілюструють творче перевтілення традиції, коли обов’язковість та знеособленість ритуалу і канону заміняється живим інтересом, реальними бажаннями та особистими потребами, що забезпечується колективною інтерактивністю.

Ключові слова: традиція, архетип, постмодернізм, неотрайбалізм, глокалізація, наратив, минуле.

\section{ТРАДИЦИЯ И АРХЕТИП: ТВОРЧЕСКИЕ ОСНОВЫ ПОСТМОДЕРНОЙ ИНТЕРПРЕТАЦИИ}

Аннотация. Проанализировано концептуальное поле постмодернистской интерпретации соотношения традиционного и инновационного в анализе социальных взаимодействий на основе архетипного подхода. Подчеркивая единство теоретических основ постмодернизма, постструктурализма и деконструктивизма, рассматриваются постмодерные практики демонстрации способности человека и сообществ жить в условиях нестабильности, хаотичности и плюральности, за счет, в частности, взаимопроникновения новых и архаичных форм социальности. Архетипная природа традиций в нарративной постмодерной практике ярко проявляется в интерпретативных сюжетах-играх и многочисленных перспективах “прочтений” архетипных образов, деконструкциях традиционных способов представления архетипов в ироничном диалоге с близким и далеким прошлым.

В рамках теоретико-методологических основ постмодернизма исследуются теории альтернативных форм самоорганизации, которые приходят на смену модерным формам социализации и базируются на различении социальной и культурной реальности. Обращая внимание на усиление глокальных контекстов глобализации, раскрыт предложенный М. Маффесоли феномен неотрайбализма, который базируется на таких выразительных постмодерных ценностях, как контекстуальная симпатия, общинная эмпатия, инклюзивное разнообразие, плюральная толерантность, эклектичность и традиционность. Утверждается, что неотрайбализм является отражением подлинной духовной революции современного информационного общества в аспекте формирования новой сетевой социальности на основе свободного выбора культурных ценностей и пропаганды культурно “близ- 
кого” образа жизни. Поэтому постмодернизм в аспекте его неоконсервативной сущности понимается как возвращение архаизма, являющегося источником жизненной силы и органической мобилизации коллективной энергии. Неотрайбы как экзистенциальные сети “живой социальности” иллюстрируют творческое перевоплощение традиции, когда обязательность и обезличенность ритуала и канона заменяется живым интересом, реальными желаниями и личными потребностями, что обеспечивается коллективной интерактивностью.

Ключевые слова: традиция, архетип, постмодернизм, неотрайбализм, глокализация, нарратив, прошлое.

\title{
TRADITION AND ARCHETYPE: CREATIVE FOUNDATION OF THE POSTMODERN INTERPRETATION
}

\begin{abstract}
The article will attempt to outline the conceptual field of postmodern interpretation of the correlation between the traditional and the innovative in the archetypal approach to analyzing social interactions. The author accentuates the accord of the theoretical foundations of postmodernism, poststructuralism and deconstructivism, gives an account of the postmodern practices that demonstrate the ability of individuals and communities to live under conditions of instability, chaos and plurality due to various factors, among which interpenetration of new and archaic forms of sociality can be found. The archetypal nature of traditions in the postmodern narrative practice appears clearly evident in interpretive game stories and numerous outlooks on the "perusals" of the archetypal images, as well as in deconstructing the traditional methods of introducing archetypes in an ironic dialogue with the near and the distant past.

Basing on the theory and methodology of postmodernism, this paper discusses the theories of the alternative self-organization forms that tend to replace modern forms of socialization and rely on the distinctions between social and cultural realities. While paying attention to the increasing global contexts of globalization, the research critically reviews the phenomenon of neotribalism, as introduced by M. Maffesoli, based on such prominent postmodern values as contextual sympathy, community empathy, inclusive diversity, plural tolerance, eclecticism and conventionality. The author argues that neotribalism is a mere reflection of the true spiritual revolution of the modern information society in terms of building a new network sociality based on the free choice of cultural values and promoting a culturally "close-knit" lifestyle. Therefore, postmodernism in the aspect of its neoconservative essence is understood as the returning archaism, which is a source of vital energy and organic mobilizing of the collective energy. Neo-tribes, representing existential networks of "live sociality", illustrate a creative reincarnation of the tradition, when vital interests, real desires and personal needs are being conveyed by the collective interactivity ousting at the same time the obligatoriness and impersonality of the ritual and the canon.
\end{abstract}

Keywords: tradition, archetype, postmodernism, neotribalism, glocalization, narrative, the past. 
Постановка проблеми. Парадоксальність сучасності, концептуалізована багатьма дослідниками у суперечностях універсалізму, прогресивізму, індивідуалізму, інструментального активізму, раціоналізму тощо, потребує вироблення нових принципів організації суспільного буття, враховуючи численні системні кризи та ескалацію загроз глобального характеру (екологічних, екзистенційних, політичних тощо). Потреба виявлення глибинних джерел та чинників смислових конфігурацій світоглядних форм сучасності зумовлює звернення до аналізу тенденцій і особливостей взаємодії традиційного та інноваційного, прихованого та явного, зважаючи на динаміку та наслідки глобально-глокальних змін соціальної реальності постіндустріальної доби, а також неоднозначність процесів демократизації, лібералізації, “плинної” ідентифікації тощо.

Виразні вектори невизначеності, вразливості, нестійкості, незахищеності, поляризації, нерівномірності задають як нові можливості (розглянуті, зокрема, в синергійний та постмодерній методології), так і провокують нові виклики та загрози, актуалізуючи питання формування та збереження ідентичності, інтеграції, легітимації тощо. Кардинальні зміни в різноманітних сферах сучасного соціуму, пов'язані, зокрема, з кризою попередніх світоглядних настанов та переходом у царину постмодерної культури, проблематизують минуле в різноманітних контекстах та взаємопроникненнях традиційно-символічного і сучасного. Зауважимо, що філософська традиція має дав- ню практику звернення до метафоричних, есеїстичних та міфологічних засобів у цілком раціональному дискурсі (від діалогів Платона до постмодерної доби), увиразнюючи у міфо-поетичних та символічних образах глибокі сенсоутворювальні ідеї, демонструючи їх надзвичайну переконувальну та інтерпретативну спроможність.

Аналіз останніх досліджень і публікацій. Серед дослідників проблематики взаємодії традиційного та новаторського в умовах глобалізації та інформатизації варто виокремити У. Бека, І. Валерстайна, 3. Баумана, Р. Робертсона, М. Маклюена, М. Кастельса, Е. Гіденса, К. Лоренца, С. Жижека, К. Хюбнера, які досліджують суперечливі контексти глобально-глокальних процесів та фіксують значні зміни соціальності в нових умовах технізації, інформатизації, економізації, медіатизації тощо.

Дослідження символічної та комунікативної природи архетипів, а також специфіки їх прояву в соціальній та політичній реальності знаходимо в працях К. Г. Юнга, М. Еліаде, А. Аугустинавічуте, К. Пірсон, М. Марк, С. Кримського, Е. Афоніна, О. Донченко та ін., які виокремлюють в суспільній свідомості неусвідомлювані інтуїтивні структури досвіду попередніх поколінь людства, здійснюють архетипові типології, зосереджуючись на аналізі універсальної природи архетипів та їх органічної адаптивності.

Питанням трансформацій соціальної реальності в постмодерній інтерпретації присвячені праці Ж.-Ф. Ліотара, Р. Барта, Ж. Лакана, 
Ж. Бодріяра, М. Маффесолі, Ж. Деріда, Ж. Дельоза, Ф. Гватарі, М. Фуко, У. Еко, Ю. Кристевої, Ф. Джеймісона, П. Андерсона, П. Козловськи та ін., які досліджують післятрансформаційний стан культури та здійснюють спроби виявити давні смислові конструкти соціокультурних процесів сучасності, віднайти опорні онтологічні основи в умовах соціокультурної невизначеності, акцентуючи увагу на невпорядкованості, плюральності, стиранні відмінностей між бінарними опозиціями (реальне/ірреальне, раціональне/ ірраціональне, елітарне/масове, високе/низьке, суб'єкт/об'єкт, центр/ периферія). Означені риси концептуалізуються, зокрема, в поняттях “симуляціï" та "гіперреальності" Ж. Бодріяра [1], “наративності” Ж.-Ф. Ліотара [2], “ризоми” Ф. Гватарі та Ж. Дельоза [3], “неотрайбалізму” М. Маффесолі [4], “пастішу” Ф. Джеймісона [5] та ін. Водночас, залишається недостатнім виявлення концептуального зв’язку традицій та архетипів в умовах сучасного глобалізованого соціуму, а також потребують детального аналізу нові ідентифікаційні практики соціальності постмодерної доби.

Відтак, метою цього дослідження є конкретизація концептуального поля постмодерної інтерпретації співвідношення традиційного та інноваційного в аналізі соціальних взаємодій 3 позицій архетипового підходу.

Виклад основного матеріалу дослідження. Стан постмодерну з’являється як літературно-критично-філософська реакція на кризу суспільних та цивілізаційних цін- ностей другої половини ХХ століття, а також внаслідок потреби у виробленні нових шляхів розвитку в умовах втрати так званих супер-засад епохи Модерну - ідей Бога, Прогресу, Істини, Автора, Суб'єкта тощо. Однією з виразних характерних рис постмодернізму, на думку Ж.-Ф. Ліотара, є саме втрата довіри до цих метанаративів Модерну, сам метанаративний механізм легітимації знання знепотрібнюється, а класичні орієнтири оптимізації, ефективності, результативності призводять до логіки внутрішньої парадоксальності [2, с. 10-11]. Натомість постмодерн демонструє спроможність людини та спільноти жити в умовах нестабільності, з'являється емансипативна сила та чутливість до відмінностей, зростає здатність витримувати взаємонеспівмірності, що увиразнює світоглядні орієнтири постмодерну в аспекті визнання мінливості, неоднозначності, плюральності, хаотичності.

Унікальний стиль гіперрефлексії, базований на поєднанні теоретичних основ постмодернізму, постструктуралізму та деконструктивізму, зорієнтований на дослідження метаморфоз сучасності та "впізнаванні" ix історичних асоціацій у культурі та природі, демонструючи модифікації культурної традиції та виявляючи ii плюралістичність. Окреслені тенденції зумовлюють підстави означення постмодернізму як неоконсерватизму, що у творчих інтерпретаціях традиції увиразнює специфічно-іронічний, формально-пародійний (без почуття гумору), ностальгічний, інтелектуально-ігровий, евристичний, сенсопороджувальний потенціал в 
утвердженні множинності та нестійкості.

Загалом традиція є своєрідним засобом накопичення, збереження та передачі суспільного досвіду (включно з об'єктами, процесами та способами наслідування) наступним поколінням, акцентуючи етноментальні особливості як сутнісні, актуальні, конкретно-національні. Етимологічне підгрунтя традиції як “передавальної” спроможності відображає тенденції трансляції безпосередності смислів життєвого світу та живої присутності. Сама традиція, за вдалим висловом А. Срмоленка, завжди сполучена з певним місцем (Ort), укорінена саме в цій землі (Boden), саме в даному просторі, peгіоні. Вона тісно пов'язана з тут-буттям людини (Dasein), з місцем, де вона народилась і де вона в себе вдома (Zu-Hause-sein), з тією місцевістю, яка є i малою батьківщиною [6, с. 137]. Локальність традиції та їі здатність до тривалої відтворювальної актуалізації забезпечують людині узвичаєння життєвих орієнтацій в мінливих умовах, задаючи смислові контексти орієнтативних взаємодій зі світом, з іншими людьми, собою та постаючи символічними кодами комунікативних детермінант “етики ближнього” та “етики дальнього”. Завдяки відчутному адаптивному потенціалу традиція полегшує пристосування до мінливих умов навколишнього середовища, пропонуючи апробовані способи діяльності та повсякчас актуалізуючи відповідні поведінкові паттерни.

По суті традиція є стабілізативним соціальним механізмом, який на індивідуальному рівні схематизує думки та дії, а на міжособистісному формує структуру очікувань, яка впорядковує та координує соціальні взаємодії, забезпечуючи відносини довіри як основи життєвого світу, коли людина знає, що зазвичай може очікувати від інших в типових ситуаціях. Постмодерне розуміння традиції впроваджує парадигму плюралістичності та внутрішньої трансформації в концепцію своєрідного ігрового освоєння хаосу та перетворення його в звичне середовище існування шляхом актуалізації, в тому числі, архетипних складових в альтернативному теперішньому, що має місце в наявних тенденціях формування соціокультурного простору та сучасних ідентифікаційних практиках.

В юнгіанській традиції архетипи та архетипні образи (які мають також давні аналоги в численних філософських системах від Платона до I. Канта, Г. Гегеля, А. Шопенгауера та ін.) зазвичай розуміються як праобрази універсальних міфологічних мотивів та сюжетів, які відображають типові психічні властивості, характерні поведінкові реакції та переживання, що походять із загальнолюдського досвіду та мають універсальні характеристики. Архетипи як глибинні шари колективного несвідомого по суті являють собою апріорні когнітивні схеми первинних образів, які наповнюються конкретним змістом в реальних умовах життя та відповідним чином активізують і спрямовують психічну енергію, спонтанним чином організують сприйняття, уяву, пам'ять, переживання, реакції. Архетипи постають репрезентацією колективного досві- 
ду, увиразнюючись в традиції як способі обробки та трансляції архетипових образів шляхом оприявнення фундаментальних якостей та типових рис певних спільнот. Саме неявний характер архетипових образів та їх виразний наративний характер в міфологічних проекціях уможливлює їх постмодерну інтерпретацію в аспекті поєднання одночасно індивідуального втілення унікальним чином загально-повторюваної моделі, властивої багатьом, враховуючи більш широкий несвідомий контекст організації колективного життя.

Наголосимо, що К. Г. Юнг заперечував розуміння архетипів як конкретних міфологічних образів та мотивів, розуміючи архетипи насамперед як спрямовані тренди психічної енергії, тенденції до формування уявлень, інстинктивні вектори та відповідні мисленнєві форми [7]. Специфічний зміст архетипів з'являється лише в індивідуальному житті, коли в ці форми потрапляє особистий досвід. Архетипічні ідеї К. Г. Юнг відносить до непорушних засад людського духу, підкреслюючи їх вічне повторення та перетворення, що має виразні постмодерні конотації: “Як би довго вони не залишались в забутті, вони завжди повертаються, досить часто в дивовижно перетвореному вигляді і з якимось особистісними вивертами або інтелектуальними перекрученнями..., вони завжди відтворюють себе в тих чи інших нових формах, виступаючи вічною істиною, яка внутрішньо притаманна людській природі” [8, c. 120].

Архетипи колективного несвідомого спричиняють появу комплек- сів уявлень. Вчений звертає увагу на те, що уявлення такого роду не вигадуються, а “входять у внутрішнє сприйняття в якості готових утворень” [8, с. 192]. Саме тому слід їх розглядати як суб'єкти, що підкоряються власним законам і існують автономно, ілюструючи тенденції вічного повернення та позачасовості, до яких кожне покоління додає власні відмінності та формати втілення. Прикметно, що К. Г. Юнг звертається до символічної термінології та метафоричних образів у спробі конструктивіської концептуалізації архетипів, які мають відчутні орієнтативні, регулятивні та структурні компоненти, а саме метафор річища та незримої осьової структури, які набувають конкретних форм лише в процесі безпосереднього наповнення живим змістом, що в постмодерній традиції яскраво виявляється в інтерпретативних сюжетах-іграх в численних перспективах “прочитань" архетипних образів, деконструкціях традиційних способів представлення архетипів в іронічному діалозі 3 близьким та далеким минулим тощо.

Наративне підгрунтя постмодернізму як “живого минулого” базується на концептуалізації суспільства як павутиння лінгвістичних комунікацій та множини мовних ігор, що й розвиває у праці “Стан постмодерну” Ж.-Ф. Ліотар. Досліджуючи характер соціальних зв'язків в перспективі постмодерну, вчений звертає увагу на зміну функцій держави, появу альтернативних форматів суспільства, передачу деяких функцій (регулювання, відтворення) техніці та трансформацію політичного класу, який стає різнорідним та інтерактивним, 
а людина вбудовується у все більш складну і мобільну тканину відносин [2, с. 42-45]. В контексті проблематики творчої інтерпретації традиції префікс “пост-” для Ж.-Ф. Ліотара має насамперед значення не безпосередньої спадкоємності та лінійного руху типу повторення, а дещо на кшталт “ана-процесу”, що передбачає аналіз, анамнез, анаморфози, які демонструють опрацювання сучасністю власних смислів, переробляючи дещо “першозабуте” [9, с. 66].

Виразна постмодерна тенденція духовного стану “повернення традиціï”, коли минуле не лише давить та шантажує, а й надихає та увиразнює, знаходить свої оригінальні вираження в різноманітних проявах сучасності, зокрема, в “естетиці симуляціі” Ж. Бодріяра, “літературі виснаження та відновлення” Р. Барта, “культурних метаморфоз” Ф. Джеймісона та ін. Цю ситуацію влучно описує У. Еко, по суті характеризуючи реакційність та комунікативну адаптивність постмодернізму у відомому вислові-примітці: “Якщо минуле неможливо знищити, оскільки його знищення призводить до німоти, його варто переосмислити: іронічно, без наївності” [10, с. 469]. Відтак звернення до минулого постає не способом втечі від сучасності, а антуражем, локалізацією середовища свободи уяви, переосмисленням в інтертекстуальності.

Усвідомлення локальності ідентифікаційних цінностей та щораз більший інтерес до минулого зумовлюються прагненням пошуку культурних основ та поверненням до життя традиційного у розмаїтті форм, різноспрямованості та сти- льовій альтернативності. "Глокальні” контексти відродження традицій пропонує розглянути Р. Робертсон, концептуалізуючи глокалізацію в аспекті виклику глобалізації, реакції на глобалізацію та паралельного глобалізації процесу [11]. Зважаючи на посилені темпи глобалізації в певних галузях життя, Р. Робертсон звертає увагу на процеси та тенденції протилежного глобалізації спрямування - уваги до етнічності, регіоналізації, повернення до малих спільнот та актуалізації партикулярних цінностей. Відтак глокалізація в якості одного із наслідків глобалізації може бути розглянута як форма захисної реакції на уніфікацію і протидія “стиранню відмінностей”, редукція складнощів глобалізації, а також (в деструктивному аспекті) як маргіналізація чи вимушена ізоляція.

Продовженням глокалізаційних тенденцій та яскравим прикладом оригінального поєднання традиційного та нового в сучасних соціальних взаємодіях на тлі глобалізації є концепція неотрайбалізму М. Маффесолі, який виявляє ключові соціальні факти оновленої традиційності в поверненні соціальності в досвід повсякденності, актуалізуючи питання постмодерної ідентичності, мережевої солідарності та актуальної субсидіарності. Неотрайбалізм по суті є відображенням справжньої духовної революції сучасного інформаційного суспільства в аспекті формування нової мережевої соціальності на основі вільного вибору культурних цінностей та пропаганди культурно “близького” способу життя. Племінний міф сучасності ілюструє процеси активізації всього того, що від- 
криває тварину в людині, а племінне в соціальному [12, с. 189]. Такі спільноти демонструють “енергійний віталізм” у низці соціальних рухів та об'єднань - від екологічних, феміністичних, релігійних, музичних, спортивних, сексуальних до численних “мікрогруп" за різноманітними інтересами та вподобаннями, організованими, в тому числі, навколо актуалізованих архетипів Героя, Друга, Аніми/Анімуса, Тіні, Батька та безлічі інших, особливо якщо вони розтиражовані в сучасних медіа та підкріплені в практиках масових заходів і розважальній видовищності навколо певного неототему.

Досліджуючи ефекти відродження традиційних форм соціальності в сучасному суспільстві, зокрема, в розмаїтті численних телешоу (заснованих, в тому числі, на практиках вуайєризму), в модних тенденціях (посиленій увазі респектабельних брендів до всього дикого та етнічного) та в міській театральності, М. Маффесолі звертає увагу на поширення колишніх фестивальних та карнавальних практик, які базуються на спільній участі, чуттєвості та поверненні до образності [12, с. 191-192]. Зазначимо, що карнавалізація у вигляді тематичних фестивалів (на основі локальної ресурсності - історичної реконструкції, місцевих гастрономічних особливостей, численних туристичних переваг) стає відчутним компонентом брендингу території, увиразнюючи вдале поєднання сили місця та творчого відродження традиції, а також постаючи індексом соціальної життєздатності.

Для означення інтегративної ролі специфічної племінної емоційності
M. Маффесолі застосовує поняття “селективної соціальності” [4, c. 127], ілюструючи методологічний інструмент співчутливості як нової парадигми соціального зв’язку та редукції щодалі складнішого світу. Такі “символічні” способи соціальної взаємодії демонструють тенденції повернення до архаїчних, фундаментальних значень, забезпечуючи органічний зв'язок та горизонтальну довіру завдяки архетипічному субстрату. Відтак спосіб соціальної організації неотрайбів як “живої соціальності” відповідає природним спроможностям самоутворення, саморегуляції та самоідентифікації (тому і чисельність членів такої спільноти має бути невелика, до декількох сотень, щоб зберегти горизонтальну взаємодію, “тактильність” та уможливити консенсус спільної участі), на противагу вертикальним дисциплінарним механізмам класичних інституцій, які базуються на ієрархічних інструментах влади, примусу та контролю (що метафорично увиразнено в образі Паноптикона М. Фуко [13]). Натомість регулятивною та інтегративною основою “нових племен” є емпатійна товариськість i актуалізоване почуття приналежності та співпереживання, що реалізується завдяки своєрідному “атмосферному імперативу" общинності та фанатичної пристрасті, що й забезпечує особливу енергію колективності.

Висновки і перспективи подальших досліджень. Отже, постмодерн як своєрідний виклик сучасності та одночасно ㄲï “діагноз” характеризує суттєві зміни в конфігураціях взаємин людини та суспільства, набува- 
ючи гібридних ознак техно-антропоморфоного характеру. Дослідити, або, принаймні, описати основні тенденції цих змін постмодерна методологія береться шляхом акцентування ролі традиції в символічному лабіринті та мережі наративних ігор з перетворення архетипів, визнання ідей повторення та повернення до основ, фокусуючи увагу на історичних контекстах інтерпретації шляхом деконструкції та реструктуризації, усвідомлюючи наївність тотального прогресизму та заперечуючи властивий глобалізації універсалізм.

Неотрайбалізм як увиразнення глокальних тенденцій сучасності базується на таких виразних постмодерних цінностях, як контекстуальна симпатія, общинна емпатія, інклюзивне розмаїття, плюральна толерантність, еклектичність та традиційність (в сенсі дешифрування традиції). Останнє зумовлює трактування постмодерної ідентичності як живої суміші старого і нового, як активної присутності минулого в розмаїтій мережі соціальних солідарностей. Постмодернізм може бути розглянутий як активно посилене повернення архаїзму, що є джерелом життєвої сили та органічної мобілізації колективної енергії. Неотрайби як екзистенційні мережі “живої соціальності” ілюструють творче перевтілення традиції, коли обов'язковість та знеособленість ритуалу і канону заміняється живим інтересом, реальними бажаннями та особистими потребами, що забезпечується колективною інтерактивністю. Творча актуалізація архетипів як спонтанних структур колективної пам'яті та історичної свідомості, наявних в смислових контекстах традицій, ілюструє зв'язок між минулим та майбутнім, що й забезпечує орієнтири цілісності в умовах невизначеності. Наголосимо, що архетип має відчутні ознаки культурного явища, відображаючи архаїчні елементи колективного несвідомого та постаючи своєрідними когнітивними зразками i символічними формами внутрішнього досвіду, демонструючи підпорядкування соціального культурному в релятивізації та плюралізації ідентичності.

\section{СПИСОК ВИКОРИСТАНИХ ДЖЕРЕЛ}

1. Baudrillard J. Simulacres et simulation. Paris: Galilée, 1981. 235 p.

2. Лиотар Ж.-Ф. Состояние постмодерна : пер. с фр. Москва: ИЭС, Санкт-Петербург: Алетейя, 1998. $160 \mathrm{c}$.

3. Deleuze G., Guattari F. A thousand plateaus. Capitalism and Schizophrenia. London: University of Minnesota Press, 2005. 629 p.

4. Маффесолі М. Час племен. Занепад індивідуалізму у постмодерному суспільстві. Київ: Вид. дім "Києво-Могилянська академія”, 2018. $264 \mathrm{c}$.

5. Jameson F. Postmodernism, or the cultural logic of late capitalism. Durham: Duke University press, 1991. 438 p.

6. Ермоленко А. Н. Этика ответственности и социальное бытие человека (современная немецкая практическая философия). Киев: Наук. думка, 1994. 200 с.

7. Юнг К. Г. Архетип и символ. Москва: Канон, 2016. 336 с.

8. Юнг К.Г. Ответ Иову. Москва: АСТ, 1998. 384 c. 
9. Лиотар Ж.-Ф. Заметка о смыслах пост. После времени: французские философы постсовременности / Иностранная литература. 1994. № 1. С. 54-66.

10. Эко У. Заметки на полях "Имени розы" / Эко У. Имя розы : пер. с итал. Москва: Книжная палата, 1989. C. 468-481.

11. Robertson R. Globalization: Social Theory and Global Culture. London: Sage publications, 1992. $211 \mathrm{p}$.

12. Maffesoli M. Iconologias. Nuestras idolatrias posmoderas. Barselona, Ediciones Peninsula, 2009. 204 p.

13. Foucault M. Surveiller et punir. Naissance de la prison. P: Gallimard, 2004. 318 p.

\section{REFERENCES}

1. Baudrillard, J. (1981). Simulacres et simulation. Paris: Galilée [in French].

2. Lyotard, J.-F. (1998). Sostoyanie postmoderna [The postmodern condition]. (N. Shmatko, Trans). Moskow: Aletejya [in Russian].

3. Deleuze, G., Guattari, F. (2005). A thousand plateaus. Capitalism and Schizophrenia. London: University of Minnesota Press.

4. Maffesoli, M. (2018). Chas plemen. Zanepad indy'vidualizmu u postmodernomu suspil'stvi [The time of tribes. The decline of individualism in postmodern society]. (V. Pliushch, Trans). Kyiv: Vy'd. dim "Ky'yevoMogy'lyans'ka akademiya” [in Ukrainian].
5. Jameson, F. (1991). Postmodernism, or the cultural logic of late capitalism. Durham: Duke University press.

6. Ermolenko, A.N. (1994). Etika otvetstvennosti i social'noe bytie cheloveka (sovremennaya nemeckaya prakticheskaya filosofiya) [Ethics of responsibility and social being of man (modern German practical philosophy)]. Kyiv: Naukova dumka [in Russian].

7. Jung, K. G. (2016). Arhetip i simvol [Archetype and symbol]. Moskow: Kanon [in Russian].

8. Jung, K. G. (1998). Otvet Iovu [The Answer to Job]. Moskow: AST [in Russian].

9. Lyotard, J.-F. (1994). Zametka o smyslah post. Posle vremeni: francuzskie filosofy postsovremennosti [A note on the meanings of the post. After time: French philosophers of postmodernity]. (A. Garadzha Trans). Inostrannaya literature - Foreign literature, 1, 54-66 [in Russian].

10. Eco, U. (1989). Zametki na polyah "Imeni rozy" [Notes in the margin of "The name of the rose"]. Eko U. Imya rozy [The name of the rose] (E. Kostiukovych Trans). Moskow: Knizhnaya palata [in Russian].

11. Robertson, R. (1992). Globalization: Social Theory and Global Culture. London: Sage publications.

12. Maffesoli, M. (2009). Iconologias. Nuestras idolatrias posmoderas. Barselona: Ediciones Peninsula.

13. Foucault, M. (2004). Surveiller et punir. Naissance de la prison. Paris: Gallimard. 